\title{
9. LIFELONG GUIDANCE IN FINLAND
}

\author{
Key Policies and Practices
}

\begin{abstract}
Finland has a long history of good collaboration between the educational and employment sector regarding lifelong guidance, specifically career guidance. Today, this manifests as having a national strategy for lifelong guidance, good access to high quality services and innovative pilots such as the One-Stop Guidance Centres for youth. The new government led by Prime Minister Sanna Marin has decided to put even more efforts into lifelong guidance. This chapter describes what has been done and what future challenges lie ahead.
\end{abstract}

\section{INTRODUCTION}

Finland has a long history of career guidance programmes and policies that help individuals to develop the skills to move effectively through learning and work (Kasurinen \& Vuorinen, 2008; Merimaa, 2018). The services are provided mainly by two established public systems. The Ministry of Education and Culture is responsible for the organisation and funding of guidance and counselling services in comprehensive and upper secondary schools and in higher education. In comprehensive and upper secondary level education career guidance is a scheduled compulsory element in curriculum and a student entitlement. The Ministry of Economic Affairs and Employment is responsible for establishing political guidelines and strategic goals for the national labour market policy. Guidance and counselling services provided by the 'Employment and Economic Development Offices (TE Offices)' complement school-based services as they are mainly targeted at clients outside of education and training institutions. There has been a clear division of labour as well as long co-operation between these two systems.

\section{EVOLUTION OF GUIDANCE SERVICES IN EMPLOYMENT SETTINGS}

Professional vocational guidance and counselling began in Finland in 1939 when a psychologist's position was created in the employment office in Helsinki (Nummenmaa \& Sinisalo, 1997). The pioneering career counsellor and counselling psychologist was professor Niilo Mäki, who worked in the office from 1941 to 1946 
(e.g. Kiianmaa \& Pulliainen, 1989; Tapaninen, 2006). In 1948 the International Labour Organization (ILO) Convention 88 on public employment services gave a recommendation that all nations should provide a free public employment services. During the 40s and 50s, 13 Finnish municipalities became involved in career guidance and established vacancies for vocational psychologists (Nummenmaa et al., 1997). In the 1960s, the position of career guidance as part of Finnish employment policies and practices strengthened further when it was written in the law (Suomen asetuskoelma, 1960). A nationwide organisation of vocational guidance offices was developed under the labour administration and in the 1970s vocational guidance offices and employment offices, were joined into one employment service (Nummenmaa et al., 1997) under the Ministry of Employment.

The labour administration in Finland was reorganised in the late 1980's and regional employment agencies were changed to regional centers for trade and employment. In this new context the role and position of vocational guidance was diminished in regional administration (Vuorinen, Leminen, \& Pulliainen, 2014). A new, efficient way to address the needs of individual customers was developed in the employment offices through the tiering of services into self-help, group-based services and intensive case-managed services, including individual counselling (Sultana \& Watts, 2006).

In 2007, the Ministry of Trade and Industry and the Ministry of Labour were merged into the Finnish Ministry of Economic Affairs and Employment. The regional administration was reorganised into 15 Centres for Economic Development, Transport and the Environment (ELY Centres). One year later in 2009 the employment offices were renamed similarly as 'Employment and Economic Development Offices (TE Offices)'. Subsequently the vocational psychologists started working in a branch named 'vocational development services' in co-operation with educational advisors, vocational training advisors, rehabilitation advisors and advisors for labour market training. In 2013, the vocational psychologists started to work within all the three service lines with the overall service model:

\section{Employment and Business Services}

2. Business Competence Development Services

3. Supported Employment Services

The reform of national employment and economic offices was based on the goals of the national strategies on employment and entrepreneurship. The underlying principles in the reform were customer-orientedness, equal access, societal efficiency and productivity. Attention was given to core functions: the supply of skilled labour, fast placement of job-seekers. As an outcome of the reform the traditional vocational guidance came to an end as an organisational stand-alone service and the previously separate concepts of 'vocational guidance', 'educational advice' and 'vocational rehabilitation' were merged into one concept 'vocational guidance and career planning' (Vuorinen et al., 2014). 


\section{INTEGRATION OF CAREER GUIDANCE WITHIN EDUCATION SYSTEM}

As the vocational guidance services reached a sustainable status in the employment sector in the 1970s, the vocational psychologists visited schools and provided career guidance in co-operation with a network of designated career teachers. In 1970, Finland started a major school reform process and the formal dual system was transformed into a nine-year comprehensive education system. At that time, career education was embedded in the national core curricula as a compulsory subject for all students (Kasurinen \& Vuorinen, 2008; Merimaa, 2018). In the 1980s school counselling was integrated into upper secondary general education and vocational secondary level education as well.

In general, guidance services are provided and co-ordinated by full-time school counsellors, who are employed by the schools. They are in charge of the timetabled career education sessions, group activities, individual guidance and co-operation with employers and stakeholders. School counsellors co-operate with group tutors who support their own students on daily activities. Also, all teachers are expected to instruct their students in study skills in particular. In vocational education and training (VET) career education is integrated into all vocational subjects and the transition skills are developed in co-operation with local employment and economic offices, companies and local youth services (FNAE, 2016a, 2016b).

In 2002, the National Board of Education conducted an evaluation of guidance in basic and upper secondary level education. According to the results, students received information on how to apply to secondary or tertiary education but less current labour market information. The focus of the career education programmes was on the completion of programmes rather than transitional issues from lifelong learning perspective (Numminen \& Kasurinen, 2003). As a response to this, the subsequent reforms of the national core curricula (FNAE, 2016a, 2016b; Opetushallitus, 2004) emphasised the career development process and acquisition of career management skills and entrepreneurial skills in all grade levels from primary school through to secondary schools and in vocational streams. The European Lifelong Guidance Policy Network (ELGPN, 2012, 2015a) defines Career Management Skills (CMS) as 'a range of competences which provide structured ways for individuals and groups to gather, analyse, synthesise and organise self, educational and occupational information, as well as the skills to make and implement decisions and transitions' (ELGPN, 2012, p. 21).

The reform in upper secondary education in the 1990s emphasised co-operation between general and vocational education with flexible programmes and the right mix of guidance and education opportunities to ensure that there are no dead ends once students have graduated (Numminen \& Kasurinen, 2003). General education and vocational qualifications became more equal as students could obtain general eligibility for higher education from both tracks. Thus career education acts as a link between the school, community and working life. It promotes social justice, equity, equality and inclusion and prevents marginalisation from education and 
employment (Hooley, 2014). As a compulsory curriculum entitlement, it provides an opportunity to reflect on future options with the whole age cohort and it is a cost-effective measure for preventing drop-outs and further social exclusion. The knowledge and skills developed in career education contributes to the availability of the skilled labour force and the balance between the demand and supply of skills and competences in the future labour market (OECD, 2004).

Working life, careers and attitudes towards work in Finland are going through large and dynamic changes. There is a rising demand for learning across all levels of qualifications (Blossfield, Kilpi-Jakonen, Vono de Vilhena, \& Buchholz, 2014). This is due to an increasing share of knowledge work, rapid skills renewal, and strong focus on innovation and development, in parallel with an ageing work force and growing skills shortages (Tikkanen \& Nissinen, 2016). It has been estimated that in each year approximately 400,000 Finns change jobs (Lindholm, Kesä, Kukkonen, Jämsen, \& Hyttinen, 2017). In the last few years structural and longterm unemployment have been quite high in Finland (e.g. Duell, Thurau, \& Vetter, 2016; European Commission, 2016a, 2016b, 2016c) and the unemployment rate has been higher than in other Nordic countries (OECD, 2018). However, during 2018 we have seen a positive trend in the labour market (e.g. OECD, 2019; Official Statistics of Finland, 2018). Finland is now facing a shortage of skilled workers in some areas. For instance, there are not enough information and communication technology (ICT) specialists. According to the OECD Skills for Jobs database (2018), more than 9 in 10 of all job openings in Finland (including replacements for vacated jobs) between now and 2030 will be for high- or medium-level qualifications. The average across the other OECD countries is 5 in 10 jobs. Demands for competences and skills are getting more varied and more challenging all the time. Education is becoming the new insurance for independent livelihood.

Finland has also adopted the European Flexicurity agenda (Council of the European Union, 2007) as a response to the changing world of work and structural changes in the job markets. Flexicurity attempts to reconcile employers' need for a flexible workforce with workers' need for security. It tries to ensure that whereas employees might more easily lose their job, they are less likely to lose their livelihood (Sultana, 2012). Since 2005, an operational model of change security targeted for workers dismissed for economic reasons or those at risk of dismissal has facilitated employees to shift from one job to another. The legislation regarding change security in the competitiveness agreement entered into force 2017. The employer has to offer the employees that they have dismissed for economic reasons coaching and training which enhance the employability of the employee. The employer finances this training and its value should be equivalent to the pay of the employee.

The flexicurity in the labour market has also been enhanced by changes to the social security system and principle of lifelong learning. For example, more emphasis has been put on the possibility to study while receiving employment benefit and labour market training has been developed more towards fitting labour market needs. 


\section{LIFELONG GUIDANCE IN FINLAND TODAY}

Like in many countries, in Finland guidance is distributed across educational, labour market, social and health provision, under different ministries and other jurisdictions (schools, tertiary education, public employment services, social partners, the voluntary sector, the private sector, different projects). All providers are facing a growing demand for guidance whilst also having to deal with the need to make savings. In order to avoid overlapping services a new trend has emerged towards cross-sectoral networks in guidance services (Nykänen, Saukkonen, \& Vuorinen, 2012) and flexible development of the totality of guidance services. (Spangar, Arnkil, \& Vuorinen, 2008). Key features in a well-functioning service network are collaborative and dialogical creation of knowledge, inclusive collaboration and emergent development of new type of leadership and management in networks (Nykänen, 2011).

The Finnish Ministry of Economic Affairs and Employment and the Ministry of Education and Culture established a national lifelong guidance working group in 2010 and extended its mandate in 2011 into the National Lifelong Guidance Coordination and Cooperation Group. The goal of this national representative structure is to enhance national, regional and local information, advice and guidance services with a lifelong approach, support the implementation of the Youth Guarantee Initiative and strengthen multi-administrative and multi-professional co-operation among the service providers and policy makers. The national working group is cochaired by the Ministry of Education and Culture and the Ministry of Economic Affairs and Employment with close co-operation between these two sectors. In addition to these two ministries, the group consists of representatives of different ministries and agencies related to them and different education and labour related unions and students' organisations. The group has defined the following strategic objectives for developing lifelong and life wide guidance in Finland (Opetus- ja kulttuuriministeriö, 2011):

- services will be equally accessible for all and they meet the individual needs;

- individual career management skills will be strengthened;

- those who work in the field of guidance will have the required knowledge, skills and competences;

- a quality assurance system for guidance will be developed; and

- the guidance system will function as a coherent and holistic entity.

In addition, the group has given several recommendations on for example multiprofessional guidance services, the development of digital services and the education and recruitment of guidance professionals.

In 2013, the regional Centres for Economic Development, Transport and the Environment (ELY-centres) were given the task of coordinating the development work on lifelong guidance provision in their own region by means of regional lifelong guidance working groups with representatives of the service providers 
and key stakeholders. This new coordination model for guidance services has been implemented in accordance with the above mentioned five strategic goals for lifelong guidance. The following sections of this chapter include brief overviews of the current services in different sectors.

\section{Career Education and Guidance Counselling as a Student Entitlement in Education}

The Basic Education Act $(628 / 1998, \S 11)$ states that every pupil is entitled to adequate career guidance services $(\S 30)$. Guidance services in upper secondary general education (Lukiolaki, 714/2018) and in vocational schools (Laki ammatillisesta koulutuksesta, 531/2017) are similarly prescribed by law.

In comprehensive education, career education is a compulsory element in the curriculum, comprising 76 hours of scheduled activities in students' timetables during classes 7-9. In addition, there is an entitlement for individual guidance and group counselling, and practical work-experience periods in companies. In grades $1-6$, guidance is embedded in the work of the classroom teachers. Since 2016, the compulsory time slot for career education in the upper secondary level general education also totals of 76 hours. The students are further entitled to have access to career guidance for one year after graduation (FNAE, 2016a, 2016b).

The National Agency for Education defines the core curriculum but requires the approach to delivery to be organised locally. The local institutional curriculum must include a description of co-operation with the local labour market and business community. Classroom visits by labour market representatives, visits to workplaces, project work, the use of different sectors' information materials and introduction-toworking-life periods are central parts of this co-operation. The instruction in the other school subjects is to include modules that connect the knowledge and skills provided by the subject to the demands and possibilities of working life. The emphasis is on the promotion of CMS as an explicit competence area, not only on the choice of next school level. Students and their parents/guardians are to have the chance to receive information on optional elements of the curriculum as well as on the implications of these choices for the further education by meeting collectively with the teacher, school counsellor and students (FNAE, 2016a, 2016b).

During grades 7-9 the school is required to organise practical introduction-toworking life periods (TET) with personal experiences in order to create a basis for educational and career choices and to increase appreciation for work life in general. In connection with the work experience programme, students should be able to evaluate the knowledge and experience they gain. TET is normally implemented in cooperation with the other school subjects utilising their content and working methods.

Although career education has similar status as other subjects in the curricula, the students are given no credentials. Evaluation is based on students' self-assessment 
as well as on interactions, guiding and encouraging feedback in conjunction with different guidance activities. The students reflect on their progress in discussions with the teacher, they learn to evaluate their potential, their skills, their ability to act, their agency and their resources, the amount and quality of their need for guidance, their ability to work in groups and their communication skills. Students are guided to understand how their values, beliefs and people that are important to them have impact on their choices and decisions. Students learn to evaluate their skills to seek information and skills to use ICT in seeking educational and labour market information. Students are encouraged to pay attention to their skills to evaluate the reliability and relevance of various information sources. Students are guided to be aware of various self-assessment methods and tools, and to identify how they can be used in their career planning. (FNAE, 2016a, 2016b).

According to international evaluations (Holman, 2014; OECD, 2004) the integration of career education into the curriculum has been considered one of Finland's biggest strengths in guidance. In the PISA 2012 study (Sweet, Nissinen, \& Vuorinen, 2014) Finnish 15 year-olds reported that compared with many other countries they had acquired competence in many dimensions of career development. In Finland, school was seen as a substantially more important source for the acquisition of career development competence than sources outside the school.

\section{Career Services in Vocational Education and Training (VET)}

The reform of vocational upper secondary education and training in Finland (2018) requires new forms of guidance services. Instead of the previous supply-oriented approach, the government is promoting a student-oriented and demand-driven approach with competence-based modules and validation of non-formal and informal learning. Each student will have the possibility to design an individually appropriate and flexible learning path to finish an entire qualification or a supplementary skill set corresponding to their own needs. The education providers will have increased freedom in organising their activities, including career education and guidance. From the beginning of 2018 the new law on VET requires that in each 3-year programme there is a compulsory module (25-30 hours) on the development of Career Management Skills (Laki ammatillisesta koulutuksesta, 531/2017). A personal competence development plan is drawn up for every student. VET providers and their guidance counsellors are the main source of information and guidance for students, but the public employment service produce labour market information, courses and guidance for young people as well.

\section{Career Services in Higher Education}

In higher education institutes (HEIs) guidance and counselling services vary in quantity and quality (Moitus \& Vuorinen, 2003; Virolainen, 2007; Vuorinen et al., 
2005). The HEIs have autonomy in designing the services, but they are developing indicators identifying how this process is promoted and supported and monitored as a part of the quality assurance systems of the whole organisation. In general, career centers or the student affairs offices are the places where students can ask about things linked with their studies, work practice, and student grants. In faculties, there are student affairs secretaries who are responsible for students' study plans and for planning, developing and coordinating counselling services. In the universities of applied sciences (former polytechnics) career counsellors are responsible for guidance and counselling services. Academic tutors and other teachers together with peer tutors take part in counselling as agreed in the institutional plans.

\section{Services for Young People}

Studies (e.g. Salonen \& Konkka, 2017) show that young people in Finland have a new way of thinking about work. Ethical values, global issues and the significance of work matter more than before to the new generation. Still, it is not so easy to enter the labour market as a young person with limited working experience and other personal challenges to conquer.

One of the biggest success stories of guidance in Finland in recent years has been the low threshold One-Stop Guidance Centres (Ohjaamo in Finnish) (see Kettunen $\&$ Felt, Chapter 20, this volume). Following the priorities of the national strategy for lifelong guidance and the youth guarantee initiative, Finland has established a network of locally operating One-Stop Guidance Centres that provide young people under 30 years old with information, advice and guidance on a walk-in and easyaccess basis and through multiple channels (e.g. face to face, online, phone). In spring 2019, there were almost 70 One-Stop Guidance Centres. The One-Stop Guidance Centres have a national steering group chaired by the Ministry of Economic Affairs and Employment with representatives from different ministries, offices, unions and other third sector parties.

Even though there are many different support services available, some of the students in upper secondary education drop out and they especially are in a higher risk of marginalisation. According to official statistics presented in Finland's Labour Force Survey (2015), in 2015, 66000 of 16-29 year olds were NEET, representing about $10 \%$ of the age group. Seventy per cent of them were unemployed, $13 \%$ with a disability pension, $10 \%$ were taking care of children and with no information on the remaining 7\%. The network of outreach youth workers reached 26,000 youngsters in 2017 (Bamming \& Walldén, 2018). The responsibility for outreach work in Finland lies with the municipalities (youth departments). The PES, youth workshops and One-Stop Guidance Centres cooperate closely with outreach youth workers.

Youth workshops support young people aged under 29 in tackling issues related to education and training, working life and life management. The workshop activities are based on learning by doing through coaching and practical work. The workshops 
are work-oriented and communal learning environments. Youth workshop activities are mainly organised by municipalities, associations and foundations. They are available in over $90 \%$ of all municipalities. The Ministry of Education and Culture is responsible for developing the workshop activities and assists them with grants handled by the Regional State Administrative Agencies.

\section{Services for Adults}

For those over 30-years in age career guidance is more and more relevant as working life becomes more and more complex. Individuals are often seeking help to find a job or education in their 'own' field or another due to economic reasons, health problems, motivation or family situation.

The Finnish PES offers services to all citizens regardless of their employment status. For example, the TE-ASPA, customer service centre of the PES, offers distance guidance services either via phone, video or text. The employed adults are an important customer group for them. The PES also offers tests and tasks that can help an individual to clarify their interests and familiarise them with different tasks and jobs. A new digital ecosystem for PES as a joint effort with other stakeholders is on the way and promises to help people find jobs that match their skills and interests.

The main method of psychological career guidance in PES is guiding discussions, where the customers' interests, limits, opportunities and challenges are pondered. The process can also include tests and 'homework'. The aim is to support the customers to make their own decisions and to strengthen their own career management skills for future decisions. In addition to confidential psychological discussions networking and co-operation are important, when implementing the career plans and using other available PES services.

For the customers who do not need that much support, the main issues in guidance are related to surviving layoffs, raising awareness of international opportunities, support for job seeking and accessing training and coaching. Young people, lowskilled workers and immigrants usually need more support and services and their employment plan usually involves several steps.

It has been estimated that 1.9 million Finns have an illness or a disability and 600,000 of them feel that it affects their ability to get a job or continue in their current job (Sosiaali- ja terveysministeriö, 2019). If health problems, working conditions or other issues in personal life prevents someone from working in a field one has education for, an individual is entitled to vocational rehabilitation with monetary subsidy from The Social Insurance Institution of Finland or a pension company. Multisectoral Joint Service for Enhancing Employment (monialainen yhteispalvelu TYP) is an operational model in which the PES, municipalities and the national Social Insurance Institution co-operate to help people with multiple challenges to find a path towards work. The contents of vocational rehabilitation can include for example career guidance, re-education, multidimensional group coaching and work 
trials. The operational model is regulated by law (Laki työllistymistä edistävästä monialaisesta yhteispalvelusta, 1369/2014) and has a steering group chaired by the Ministry of Economic Affairs and Employment. The steering is done in close cooperation with the Ministry of Social Affairs and Health, Social Insurance Institution and representatives of the municipalities.

The services for migrants to Finland are regulated by law. Immigrants get free lessons and are required to learn Finnish or Swedish. Career guidance with interpretation can be accessed through PES and there are telephone service lines available in Finnish, Swedish, English and Russian. Russian speaking and Estonian speaking language groups are the biggest language groups of native languages in Finland. A foreign language and multicultural sensitivities provide special challenges to career guidance of immigrants. There is a special program financed by The Asylum, Migration and Integration Fund (AMIF) to develop guidance of immigrants in Finland. The city of Helsinki has piloted One-Stop Guidance Centres for immigrants. ${ }^{1}$

\section{Career Information and ICT in Lifelong Guidance}

In Finland, the Ministry of Finance steers public sector information management, structural development, and joint services and service provision. It also steers the general criteria for information security, prepares information and administrative policies and develops digital administration. Each ministry steers the development of information management and related projects in its own administrative branch.

The public guidance service provision in Finland relies more and more on online applications and tools. This follows the national strategic objectives in terms of making guidance services more easily available for all target groups to allow access to the services at a time, place and method most convenient to the users. There are several Internet portals developed by the national education and employment authorities, municipalities, different regional actors, youth information centres, etc. to serve the information, advice and guidance needs of their primary client groups. Mostly these services are available in Finnish and Swedish, often also in English.

The Ministry of Economic Affairs and Employment is building a common open-access platform (Job Market) for recruitment and competence development services of the citizens. The Ministry of Education and Culture and the Ministry of Economic Affairs and Employment have a joint high-level working group focusing on the interoperability of existing and future e-services for the citizens. The longterm goal is to develop multi-channelled career services for citizens as an integrated element of national e-governance strategies. There is also ongoing work to better integrate public digital systems and services for people struggling with their work ability. 


\section{Professionalism of Career Practitioners}

Finland has a strongly professionalised system of guidance by international standards (Andreassen, Einarsdóttir, Lerkkanen, Thomsen, \& Wikstrand, 2019; Cedefop, 2009; Vuorinen \& Kettunen, 2017;). The theoretical basis of the work and training of counsellors has been connected with the historical roots of career guidance and counselling. From the start, vocational guidance was based on psychology, and Finland's first vocational guidance counsellors were qualified psychologists (Nummenmaa \& Sinisalo, 1997). Career guidance was also one of the first fields of application in the developing science of psychology in the universities. The scientific approach goes well with testing and other methods used in psychological guidance. Some of the assessment methods developed in the employment agencies are still used in private personnel companies who provide personal compatibility assessment.

Currently, a prerequisite of a vocational guidance psychologist in the public employment services in Finland is a master's degree in psychology. The Ministry of Economic Affairs and Employment organises in-service training for all labour administration staff. Many vocational psychologists also pursue (while working) postgraduate studies in working life and organisational psychology. It is equally common to obtain a diploma in therapy, for example in cognitive, cognitive-analytic or psychodynamic therapy.

Within educational settings, the evolution of the practitioner training was integrated within the implementation of the guidance services in the reforms of education in the 1970s and 1980s The first qualified practitioners were former teachers who acted as change agents for the reform by providing information on the reform to students, parents, teachers, employers and also social partners. The first master's degree counsellor training programme started at the University of Joensuu in 1988 (Vuorinen \& Lerkkanen, 2011).

Until the mid 1990s the school counsellors for different educational levels were trained in separate programmes. The reforms of national educational strategies and the core curricula 1994 started to emphasise individual learning paths and more consistent co-operation between educational institutes on secondary level education. In 1998, the qualifications of the school counsellors in comprehensive and secondary level education were standardised in legislation. In addition to the required qualification for teachers (a master's degree or a special qualification for vocationalschool teachers), all school counsellors must have a certificate of completion of a specialist postgraduate diploma in guidance and counselling (60 ECTS). Another option is to have a master's degree in guidance and counselling (300 ECTS which includes the pedagogical training (60 ECTC) (Vuorinen \& Lerkkanen, 2011). In 2019 , there are two universities and five universities of applied sciences providing programmes which meet the legally defined qualifications. 
There has been significant improvement in professionalism during the last decade. In 2016, 97\% of the practitioners working in comprehensive and upper secondary level education had legally defined qualifications for the job. The training programmes are attractive among applicants. In 2016, only $11 \%$ of the total amount of applicants for university for university training programmes were enrolled in the actual training in universities. For the training programmes in the universities of applied sciences, 24\% of the annual applicants were approved (Kumpulainen, 2017).

In the educational sector municipalities have a statutory obligation to enable study counsellors to participate in-service training, although actual training opportunities vary from one region to another. The courses are provided by the training units, national association of school counsellors, regional administration bodies, trade unions, employer organisations and private consultants. Since the 1990's the inservice training has often been integrated with national development projects in guidance (Atjonen, Manninen, Mäkinen, \& Vanhalakka-Ruoho, 2011; Vuorinen, 2006). A remaining challenge is to support systematic professional development of the guidance practitioners. Practitioners who have completed the master's level Career Counsellor Education are eligible for scientific postgraduate education and future positions as researchers (Vuorinen \& Lerkkanen, 2011).

\section{Lifelong Guidance Services for the Future}

The field of career guidance is becoming more versatile all the time: more and more private sector companies offer guidance but also unions, rehabilitation organisations, insurance companies and employers. It will be a challenge and an opportunity to define the minimum competences of guidance professionals and to co-operate and collaborate to maintain good customer experience for those who seek guidance.

The Finnish school system is an international model of success and we have a strong belief in the formal learning system (Sahlberg, 2015). However, to comply with the labour market needs, more emphasis is needed on informal and non-formal learning. Inverse to the trend in other EU-countries, the participation of adults in non-formal learning has slightly decreased in Finland during the past decade (Eurostat, n.d.). According to OECD's Programme for the International Assessment of Adult Competencies (PIAAC), Finland has a wide gap in participation of jobrelated learning. Those with low foundation skills are less likely to participate in adult education and training than those with better skills (Musset, 2015). In addition, the improving employment rates are shadowed by matching problems - employers are having a hard time finding properly skilled workers. In 2018, 41\% of companies reported difficulties in recruiting people to jobs (Larja, 2019).

During the recent years, more and more emphasis has been placed on lifelong learning and upskilling and reskilling pathways also in Finland. A national reform for continuous learning has been enforced by the new Finnish Government (Publications of the Finnish Government, 2019) with a long-term aim to enhance more flexible education possibilities, personalised guidance and funding structures. 
This poses a challenge for the new Finnish government that has ambitious goals in raising the employment rate by putting efforts in lifelong learning and developing public services further. The new government's strategy has explicit references to lifelong guidance. The aim is to improve guidance services not only for unemployed persons, but also for those returning from extended family leave, employees and immigrants. More coherent services are planned for employees, entrepreneurs and the self-employed.

The government programme invites all stakeholders to enhance the lifelong guidance services by utilising and intensifying the existing good practices in cross-sectoral and multi-professional service provision. The aim is to enhance services for those in need of special support (including people with partial work capacity, immigrants, people with disabilities, young people and older members of the workforce). The goal is also to improve the availability of work coaches in employment and social services.

The government presents concrete measures to strengthen the career education and guidance in different levels of education e.g. by examining the optional student/ practitioner ratio and by stronger emphasis on guidance within the transition phases during individual learning paths. The capacity of first and second generation immigrants to access further studies will be improved by more structured guidance and multidisciplinary collaboration with their families.

Regarding lifelong guidance and the successful implementation of upcoming efforts of the government, the government program and the reports on continuous learning (Opetus- ja kulttuuriministeriö, 2019; Sitra, 2019) highlight these factors:

1. redefining national lifelong guidance strategy and strategic steering at national level to support cross-sectoral co-operation;

2. a jointly agreed framework for national coordination and legislation of multiprofessional guidance services for all age groups;

3. better evidence of effectiveness and impact of guidance services for different target groups (special target groups named by the government: immigrants, lowskilled, people returning from family leave, aged workers, entrepreneurs and guidance at workplace);

4. strengthening the role of PES by re-organizing and reallocating resources and strengthening individual guidance services;

5. strengthening career education and guidance at all levels of education

6. defining and promoting career management in curriculum;

7. making sure that the development of public digital ecosystems is cross-sectoral and provides tools for career development for the citizens; and

8. redefining a competence framework for career professionals.

To implement the goals set out in the government program, the above factors should be carefully considered by ministries and relevant stakeholders. To form a new national strategy on lifelong guidance, ministries need an up-to-date overview 
of the guidance system today and its gaps. Information is needed on one hand on the resources and quality of the services and on the other hand, the needs of the special target groups, and whether these needs are met. Resources have already been allocated to national studies to feed the revision of the strategy. The Ministry of Economic Affairs end Employment conducted a mapping of guidance in the PES services in the autumn 2019. The Finnish Education Evaluation Centre has an ongoing study on transitions between studies and there is a research program focusing on the impact of One-Stop-Guidance centres.

The government has set up several high-level working groups to oversee the implementation of the government program, and two of them will be most relevant from the perspective of lifelong guidance. First, the Ministry of Education and Culture has set up a parliamentary working group on continuous learning with wide consultation of views from stakeholders and citizens. Second, the Ministry of Economic Affairs and Employment has set up seven working groups to support the ministerial group on employment. One of the subgroups has a specific guidancerelated task on the mismatch of skills and labour market needs.

The mandate of the current National Lifelong Guidance Coordination and Cooperation Group was renewed in February 2020 and will have a special task to coordinate the preparation of the new strategy for Lifelong Guidance. The ministries need to decide whether they renew its mandate or revise the representative structures for national coordination. As the guidance field is becoming more varied and complex it is necessary to create ways to react more flexibly to the hastening changes in the labour market.

Transforming lifelong guidance services for the future can only be made possible by intensifying the current co-operation of government sectors and administrators and by working closer together and breaking silos. From citizens perspective there is a need for public services to develop a transparent approach to working, where the citizen's situations can be looked at as a whole, regardless of where and when and with whom they seek help. This requires even better co-operation between sectors and probably also the wider emergence of multi-professional services and a sustainable model of One-Stop Guidance Centres for all age groups.

\section{NOTE}

1 https://www.ihhelsinki.fi

\section{REFERENCES}

Andreassen I. H., Einarsdóttir, S., Lerkkanen, J., Thomsen, R., \& Wikstrand, F. (2019). Diverse histories, common ground and a shared future: The education of career guidance and counselling professionals in the Nordic countries. International Journal for Educational and Vocational Guidance, 19(3), 411-436. doi:10-1007/s10775-018-09386-9

Atjonen, P., Manninen, J., Mäkinen, S., \& Vanhalakka-Ruoho, M. (2011). Mihin ohjaus on yltänyt? Oppilaanohjauksen vuosien 2008-10 kehittämistyön vaikuttavuusarviointi [How far has career guidance reached? Impact evaluation of national guidance development projects in 2008-10]. Helsinki: Opetus- ja kulttuuriministeriön julkaisuja. 
Bamming, R., \& Walldén, J. (2018). Etsivä nuorisotyö 2017 - Valtakunnallisen etsivän nuorisotyön kyselyn tulokset [Outreached youth work 2017 - Results for the national survey on outreached youth work]. Aluehallintoviraston julkaisuja 49/2018. Länsi- ja Sisä-Suomen aluehallintovirasto.

Basic Education Act. (628/1998). Retrieved from https:/www.finlex.fi/en/laki/kaannokset/1998/ en19980628.pdf

Blossfield, H.-P., Kilpi-Jakonen, E., Vono de Vilhena, D., \& Buchholz, S. (Eds.). (2014). Adult learning in modern societies: An international comparison from a life-course perspective. Cheltenham: Edward Elgar.

Cedefop. (2009). Professionalising career guidance. Practitioner competences and qualification routes in Europe (Cedefop Panorama Series, No. 164).

Council of the European Union. (2007). Implementation of the common principles of flexicurity with the framework of the 2008-2010 round of the Lisbon Strategy - Report by the "flexicurity" mission. Brussels: Council of the European Union.

Duell, N., Thurau, L., \& Vetter, T. (2016). Long-term unemployment in the EU: Trends and policies. Bielefeld: Bertelsmann Stiftung, Hans Kock Buch- und Offsetdruck.

European Commission. (2016a). Employment and social developments in Europe 2015. Brussels: European Commission.

European Commission. (2016b). EU employment and social situation, quarterly review, Spring 2016. Brussels: European Commission.

European Commission. (2016c). EU employment and social situation, quarterly review, Summer 2016. Brussels: European Commission.

European Lifelong Guidance Policy Network (ELGPN). (2012). Lifelong guidance policy development: A European resource kit (ELGPN Tools No. 1). Saarijärvi, Finland.

European Lifelong Guidance Policy Network (ELGPN). (2015a). Designing and implementing policies related to career management skills (ELGPN Tools No. 4). Saarijärvi, Finland.

European Lifelong Guidance Policy Network (ELGPN). (2015b). The Guidelines for policies and systems development of lifelong guidance: A reference framework for the EU and the Commission (ELGPN Tools No. 6). Saarijärvi, Finland.

Eurostat. (n.d.). Adult education survey [Participation rate in education and training, aged 25-64, nonformal learning (online data codes: trng_aes_101)].

Finnish National Agency for Education (FNAE). (2016a). National core curriculum for basic education 2014 (Publications 2016:5).

Finnish National Agency for Education (FNAE). (2016b). National core curriculum for general upper secondary schools 2015 (Publications 2016:8).

Holman, J. (2014). Good career guidance. London: Gatsby Charitable Foundation.

Hooley, T. (2014). The evidence base on lifelong guidance. A guide to key findings for effective policy and practice (ELGPN Tools No. 3). Saarijärvi, Finland.

International Labour Organization (ILO). (1948, July 9). Employment service Convention No 88. Convention concerning the organisation of the employment service, C088. Retrieved from http://www.ilo.org/dyn/normlex/en/f?p=1000:12100:0::NO::P12100_INSTRUMENT_ID:312233

Kasurinen, H., \& Vuorinen, R. (2008). Lernberatung im finnischen Schulwesen. In A. Mathies \& S. Ehrenrand (Eds.), Studien zum Bildungswesen und Schulsystem in Finnland (pp. 156-165). Flensburg: Universität Flensburg.

Kiianmaa, A., \& Pulliainen, V. (1989). Niilo Mäki ja soveltavan psykologian alku Suomessa [Niilo Mäki and the beginning of the applied psychology in Finland]. Psykologia, 24, 170-182.

Kumpulainen, T. (2017). Opettajat ja rehtorit Suomessa 2016 [Teachers and headmasters in Finland 2016] (Raportit ja selvitykset 2017:2). Opetushallitus.

Laki ammatillisesta koulutuksesta [Act on vocational education]. (531/2017). Retrieved from https://www.finlex.fi/fi/laki/ajantasa/2017/20170531

Laki työllistymistä edistävästä monialaisesta yhteispalvelusta [Act on public employment and business service]. (2012). 1369/2014 Retrieved from https://www.finlex.fi/fi/laki/kaannokset/2012/ en20120916.pdf 
Larja, L. (2019). Työvoiman hankinta toimipaikoissa vuonna 2018 [Search for labour and filling of vacancies by businesses in 2018]. TEM-analyyseja 94/20.

Lindholm, T., Kesä, M., Kukkonen, P., Jämsen, P., \& Hyttinen, M. (2017). Uusi työn markkina. Ehdotus edistyksellisemmän työn markkinan luomiseksi Suomeen [New market for work. Proposal for a more foreward-looking market for work in Finland]. Sitra. Työpaperi.

Lukiolaki. [Act on General Upper Secondary Education]. (714/2018). Retrieved from https://www.finlex.fi/fi/laki/ajantasa/2018/20180714

Merimaa, E. (2018). Oppilaanohjaus tuli koululaitokseen peruskoulun myötä [Career education was implemented in schools with the reform of basic education]. In J. Pirttiniemi, H. Kasuringn, E. Merimaa, R. Vuorinen, \& J. Kettunen (Eds.), OPO 2 Opinto-ohjaajan käsikirja [OPO 2 Handbook for guidance counselors] (pp. 8-22). Oppaat ja käsikirjat 2018:1. Helsinki: Opetushallitus.

Moitus, S., \& Vuorinen, R. (2003). Evaluation of guidance services in higher education in Finland. International Journal for Educational and Vocational Guidance, 3, 159-175. doi:10.1023/ B:IJVO.0000006586.65262.b2

Musset, P. (2015). Building skills for all: A review of Finland (OECD skills studies). Paris: OECD Publishing.

Nummenmaa, R., \& Sinisalo, P. (1997). Career counseling and counselor training in Finland. Journal of Employment and Counselling, 34, 157-164. doi:10.1002/j.2161-1920.1997.tb00465.x

Numminen, U., \& Kasurinen, H. (2003). Evaluation of educational guidance and counselling in Finland. Evaluation 5/2003. National Board of Education.

Nykänen, S. (2011). Towards leadership and management in guidance and counselling networks in Finland. Finnish Institute for Educational Research, University of Jyväskylä.

Nykänen, S., Saukkonen, S., \& Vuorinen, R. (2012). Transformations in lifelong guidance provision. In P. Tynjälä, M.-L. Stenström, \& M. Saarnivaara (Eds.), Transitions and transformations in learning and education (pp. 187-202). Dordrecht: Springer.

Official Statistics of Finland (OSF). (2015). Employment and unemployment 2015. Helsinki: Statistics Finland. Retrieved from http://www.stat.fi/til/tyti/2015/13/tyti_2015_13_2016-04-12_tie_001_ en.html

Official Statistics of Finland (OSF). (2018). Labour force survey October 2018. Helsinki: Statistics Finland. Retrieved from http://www.stat.fi/til/tyti/2018/10/tyti_2018_10_2018-11-20_tie_001_ en.html

Opetushallitus. (2004). Perusopetuksen opetussuunnitelman perusteet 2004 [National core curricula for basic education 2004]. Helsinki: Edita Oy.

Opetus- ja kulttuuriministeriö. (2011). Elinikäisen ohjauksen kehittämisen strategiset tavoitteet. [Strategic goals for the lifelong guidance practice and policy development] (Opetus- ja kulttuuriministeriön työryhmämuistioita ja selvityksiä, No. 15). Helsinki: Opetus- ja kultuuriministeriö.

Opetus- ja kulttuuriministeriö. (2019). Jatkuvan oppimisen kehittäminen. Työryhmän väliraportti. [Developing continuous learning. Interim report of the working group]. Publications of the Ministry of Education and Culture, Finland.

Organization for Economic Co-operation and Development (OECD). (2004). Career guidance and public policy: Bridging the gap. Paris: OECD.

Organisation for Economic Co-operation and Development (OECD). (2018). Skills for jobs. Paris: OECD. Retrieved April 18, 2019, from http://www.oecdskillsforjobsdatabase.org

Organisation for Economic Co-operation and Development (OECD). (2019). Long-term unemployment rate (indicator). Paris: OECD. doi:10.1787/76471ad5-en

Publications of the Finnish Government 2019:33. (2019). Inclusive and competent Finland.

Sahlberg, P. (2015). Finnish lessons 2.0: What can the world learn from educational change in Finland? New York, NY: Teachers College Press.

Salonen, A., \& Konkka, J. (2017). Kun tyytyväisyys ratkaisee. Nuorten suhtautuminen globaaleihin haasteisiin, käsitykset ihanneyhteiskunnasta ja toiveet omasta tulevaisuudesta [When satisfaction rules. Youngsters' attitudes to global challenges, perceptions of ideal society and aspirations to their own future]. In S. Myllyniemi (Ed.), Katse tulevaisuudessa, Nuorisobarometri 2016 [A look to 
the future, youth barometer 2016] (pp. 137-156). Helsinki: Opetus- ja kulttuuriministeriö, Valtion nuorisoneuvosto ja Nuorisotutkimusverkosto.

Sitra [Suomen itsenäisyyden juhlarahasto]. (2019). Kohti elinikäistä oppimista. Yhteinen tahtotila, rahoituksen periaatteet ja muutoshaasteet [Towards lifelong learning. Mutual aim, funding principles and challenges for change]. Sitran Selvityksiä 150. Helsinki: Erweko.

Sosiaali- ja terveysministeriö. (2019). Kaikki mukaan työelämään-osatyökykyisille tie työelämään (OTE) kärkihankkeen tuloksia ja suosituksia [Involving all in working life. Results and recommendations from OTE key project 'Career opportunities for people with partial work ability]. Raportteja ja muistioita 2019:25.

Spangar, T., Arnkil, R., \& Vuorinen, R. (2008). Kohti ohjauksen kokonaisvoimavarojen yhteiskehittämistä. Ammatinvalinta- ja uraohjauksen kehittämishaasteiden strategisen perustan arviointitutkimus [Towards co-development of the guidance services within Finnish Public Employment Services Evaluation of strategic perspectives of the further development of career guidance services]. Työ- ja elinkeinoministeriön julkaisuja, Työ- ja yrittäjyys 30/2008. Helsinki: Edita Publishing Oy.

Sultana, R. G. (2012). Flexicurity. Implications for lifelong career guidance. ELGPN Concept Notes, No. 1. Jyväskylä, Finland: University of Jyväskylä.

Sultana, R. G., \& Watts, A. G. (2006). Career guidance in Europe's public employment services: Trends and challenges. Brussels: DG Employment and Social Services, European Commission.

Suomen asetuskoelmaA [Finland's statute-book]. (1960). Laki ammatinvalinnanohjauksesta [Vocational guidance act] (No. 43, pp. 172-174).

Sweet, R., Nissinen, K., \& Vuorinen, R. (2014). An analysis of the career development items in PISA 2012 and of their relationship to the characteristics of countries, schools, students and families (ELGPN Research Paper, No. 1). Jyväskylä: University of Jyväskylä.

Tapaninen, A. (2006). Ammatinvalinnanohjauksen tuottavuuden ja toiminnan arviointia [Evaluation of productivity of vocational guidance]. In AVO Ammatinvalinnanohjauksen vuosikirja 2006 [Vocational guidacnce year book 2006] (pp. 8-14). Helsinki: Työministeriö.

Tikkanen, T., \& Nissinen, K. (2016). Participation in job-related lifelong learning among well-educated employees in the Nordic countries. International Journal of Lifelong Education, 35(3), 216-234. doi:10.1080/02601370.2016.1165749

Virolainen, M. (2007). Workplace learning and higher education in Finland: Reflections and current practice. Education + Training, 49, 290-309.

Vuorinen, R. (2006). Internet ohjauksessa vai ohjaus internetissä? Ohjaajien käsityksiä internetin merkityksestä työvälineenä [The Internet in guidance or guidance in the Internet? Perceptions of guidance practitioners on the use of the Internet as a tool in guidance] (Dissertation, Research Reports 19). Jyväskylä, Finland: University of Jyväskylä. Institute for Educational Research.

Vuorinen, R., Karjalainen, M., Myllys, H., Talvi, U., Uusi-Rauva, E., \& Holm, K. (2005). Opintojen ohjaus korkeakouluissa - seuranta 2005. Helsinki: Korkeakoulujen arviointineuvosto.

Vuorinen, R., \& Kettunen, J. (2017). The European status for career service provider credentialing: Professionalism in European Union (EU) guidance policies. In H. Yoon, B. Hutchison, M. Maze, C. Pritchard, \& A. Reiss (Eds.), International practices of career services, credentials, and training (Chapter 6, pp. 1-15). Broken Arrow, OK: National Career Development Association.

Vuorinen, R., Leminen, A., \& Pulliainen, H. (2014). 핀란드의 직업진로지도: 핀란드 공공고용서비스에서 직업진로지도 발전 현황 [Vocational guidance in Finland: The role of psychology and vocational psychologists in the service design and provision]. International Labor Brief, 12(10), 4-8.

Vuorinen, R., \& Lerkkanen, J. (2011). Further training and distance education for career guidance counsellors - Current trends in Finland. In S. Kraatz \& B. Ertelt (Eds.), Professionalisation of career guidance in Europe (pp. 89-106). Tübingen: Dgvt Verlag. 